\title{
Becoming part of the network: French scientists and the use of English at conferences
}

David Banks

\section{(2) OpenEdition}

\section{Journals}

\section{Electronic version}

URL: http://journals.openedition.org/asp/2442

DOI: $10.4000 / a s p .2442$

ISBN: 978-2-8218-0380-0

ISSN: 2108-6354

\section{Publisher}

Groupe d'étude et de recherche en anglais de spécialité

\section{Printed version}

Date of publication: 1 December 1999

Number of pages: 209-220

ISSN: 1246-8185

\section{Electronic reference}

David Banks, « Becoming part of the network: French scientists and the use of English at conferences ", ASp [Online], 23-26 | 1999, Online since 17 August 2011, connection on 01 May 2019. URL : http:// journals.openedition.org/asp/2442 ; DOI : 10.4000/asp.2442

This text was automatically generated on 1 May 2019.

Tous droits réservés 


\title{
Becoming part of the network: French scientists and the use of English at conferences
}

\author{
David Banks
}

\section{Introduction}

1 A discourse community constitutes a network. The discourse community of a scientific discipline is a network to which the research scientist must belong if he wishes to be successful in his chosen profession. There are two major ways in which the scientist can set about establishing and maintaining himself as part of this network: publishing the results of his research in approved journals, and presenting research results at conferences. Both of these require a degree of mastery in English which is likely to pose problems for the non-anglophone scientist. In this paper I shall be concentrating on questions relating to the use of English in conferences.

2 Those of us who are interested in the analysis of scientific discourse frequently attribute opinions and attitudes to the scientists who are the objects of our study. It is appropriate to ask ourselves about the validity of this type of attribution. What sort of evidence do we have for the things we say about scientists and what they think? All too often it would seem that our statements about scientists are based on no more than hearsay, or at best the personal experience of a small number of scientific colleagues or acquaintances. This of course does not make them false, but it would be useful to have a more solid foundation for our beliefs, and some evidence that they are more than mere idées reçues.

This paper is an attempt to find some concrete evidence of the opinions and attitudes of French research scientists to the use of English in conferences. In many cases it confirms what we have generally believed, but it also throws up a few points which might warrant further research. A questionnaire was distributed to the chercheurs and enseignantschercheurs in the science and medical faculties and their associated institutes at a comparatively small French provincial university. The number of copies of the 
questionnaire sent out was 386 , though those who received it were invited to photocopy and pass it on, if they were aware of members of staff who had not received it. Consequently the number of relevant persons who ultimately received the questionnaire may be slightly more than the 386 initially sent out. The number of completed questionnaires returned was 98 . This paper is a simple presentation of the results found in the questionnaires returned.

\section{The population}

The research domains of the correspondents were as follows. A few marked two disciplines, e.g. biologie and médecine.

Table 1. Quel est votre domaine de recherche?

\begin{tabular}{|l|l|}
\hline médecine & 36 \\
\hline biologie & 21 \\
\hline physique & 11 \\
\hline chimie & 8 \\
\hline informatique & 5 \\
\hline mathématiques & 2 \\
\hline technologie & 0 \\
\hline autres (préciser) & 22 \\
\hline
\end{tabular}

5 It may be that absence of any replies for the technologie category is due to the fact that the questionnaire was not distributed to the IUTs attached to the university. Of those who marked autres, one was unspecified. One person gave his field as océanographie biologique noting that this field "differe de la biologie par sa dimension pluridisciplinaire". While no doubt true from a scientific point of view, it is arguable that this case can be assimilated to biologie for our purposes. The general area of what might be thought of as geographical studies accounted for 14 entries; 5 of these were marked as géologie, 4 as sciences de la terre, and one each for géophysique, géochimie, géographie, géoarchitechture, and géosciences. One of the entries for sciences de la terre was followed by géophysique in brackets. In addition there were three entries for électronique, and one each for océanographie, hydrographie, and histoire des sciences.

The age distribution of the population was as follows.

Table 2. Dans quelle tranche d'âge vous situez-vous?

\begin{tabular}{|l|l|}
\hline moins de 30 ans & 2 \\
\hline $30-39$ & 19 \\
\hline
\end{tabular}




\begin{tabular}{|l|l|}
\hline $40-49$ & 36 \\
\hline $50-59$ & 32 \\
\hline 60 et plus & 9 \\
\hline
\end{tabular}

It will be noted that few are under 30 , and few are over 60 . This is probably a simple reflection of the age structure of the university population.

7 Another reflection of the nature of the university population is represented in the fact that 74 of the correspondents are male and 23 female (one person did not say).

The population, as expected, is basically made up of native French-speakers. Only three did not give French as their mother tongue, and of these, two were the regional languages Breton and Alsatian; the third was the North African language Kabyle. Four correspondents claimed to be bilingual. Again, this mainly involved regional languages: two were French-Breton bilinguals, one French-Alsatian, and the fourth was a FrenchEnglish bilingual.

\section{Attendance at conferences}

Correspondents were asked how many conferences they had attended since the 1st January 1997. Since the questionnaire was distributed in late autumn 1998, this represents a period of almost 2 years. The total number of conferences attended was as follows.

Table 3. À combien de colloques/symposiums/congrès avez vous assisté depuis le 1er janvier 1997 ?

\begin{tabular}{|l|l|}
\hline en France & 411 \\
\hline dans des pays anglophones & 110 \\
\hline ailleurs & 91 \\
\hline
\end{tabular}

Some of the replies to this question were exceptional. At least three of these are worth mentioning. One correspondent said that he had attended 48 conferences in France, 4 in English-speaking countries and 1 elsewhere, giving a total of 53. A second gave 20-25 as the number of conferences attended in France, 15 in English-speaking countries and 10 elsewhere, a potential total of fifty. A third with the slightly lower potential total of 30 , gave the figures of $\geq 15$ in France, 4-5 in English-speaking countries, and 麠10 elsewhere. This means that these correspondents claimed to have been attending conferences at the rate of almost one a fortnight during this period. All three of these replies came from the medical faculty, which suggests that the question of conference attendance may have rather different implications in the medical sector compared with other branches of science. Nevertheless, even if one accepts that these figures may inflate the results to some extent, it still seems reasonable to say that on average the French scientist will attend 3 to 4 conferences in France, and 2 elsewhere, of which one is likely to be in an English-speaking country, over a two-year period. 
11 The correspondents were also asked how many papers they had given over the same period. The results were as follows.

Table 4. À combien de colloques/symposiums/congrès avez vous communiqué depuis le 1er janvier 1997 ?

\begin{tabular}{|l|l|}
\hline en France & 223 \\
\hline dans des pays anglophones & 87 \\
\hline ailleurs & 78 \\
\hline
\end{tabular}

12 The correspondents who had given high figures for the number of conferences attended, gave correspondingly high figures for the number of papers given.

\section{Languages used}

13 Correspondents were asked what languages were used at conferences. The results are as follows:

Table 5.1. Quelles langues étaient utilisées pour la présentation des communications ? En France

\begin{tabular}{|l|l|}
\hline le français & 77 \\
\hline l'anglais & 45 \\
\hline autres (préciser) & 0 \\
\hline
\end{tabular}

Table 5.2. Quelles langues étaient utilisées pour la présentation des communications ? En pays anglophones

\begin{tabular}{|l|l|}
\hline le français & 1 \\
\hline l'anglais & 59 \\
\hline autres (préciser) & 0 \\
\hline
\end{tabular}

Table 5.3. Quelles langues étaient utilisées pour la présentation des communications ? Ailleurs

\begin{tabular}{|l|l|}
\hline le français & 16 \\
\hline l'anglais & 51 \\
\hline autres (préciser) & 6 \\
\hline
\end{tabular}


It will be seen that English dominates, as one might expect, not only in English-speaking countries, but also elsewhere, where it accounts for $75 \%$.

The languages that the correspondents themselves use for their presentations were also asked for. Surprisingly, a few correspondents gave a language, even though they had not claimed to have attended a conference in the appropriate geographical area, during the stipulated period. These are presumably the languages they would have used had they given a paper. Indeed it could be argued that the text of the questionnaire can be interpreted in this way. It has been presumed that this does not distort the figures to any significant extent. The figures are as follows.

Table 6.1. Dans quelle langue présentez-vous vos communications ? En France

\begin{tabular}{|l|l|}
\hline français & 82 \\
\hline anglais & 33 \\
\hline autres (préciser) & 0 \\
\hline
\end{tabular}

Table 6.2. Dans quelle langue présentez-vous vos communications ? En pays anglophones

\begin{tabular}{|l|l|}
\hline français & 3 \\
\hline anglais & 75 \\
\hline autres (préciser) & 0 \\
\hline
\end{tabular}

Table 6.3. Dans quelle langue présentez-vous vos communications ? Ailleurs

\begin{tabular}{|l|l|}
\hline français & 16 \\
\hline anglais & 57 \\
\hline autres (préciser) & 2 \\
\hline
\end{tabular}

16 It will be seen that even in France, almost 30\% of the replies indicate papers given in English. Some replies pointed out that this corresponds to whether the conference is national or international in nature, English being used for international conferences even in France. As would be expected English is used almost exclusively in English-speaking countries, but it also dominates elsewhere. Some correspondents seem to reserve French (outside France) for countries with a French-speaking tradition, such as the countries of North Africa, or Canada.

17 These figures suggest that the French scientific researcher can expect to give an average of 2.7 papers over a 2-year period, of which 1.7 would be in English. Even if to some extent inflated, it is unlikely that this latter figure is less than 1.5 . 


\section{Form of the presentation}

18 When asked about the form of their presentations, the correspondents gave the following replies.

Table 7. Si vous communiquez en anglais, comment le faites-vous?

\begin{tabular}{|l|l|}
\hline lire un texte écrit & 28 \\
\hline parler à partir de notes & 43 \\
\hline autres (préciser) & 27 \\
\hline
\end{tabular}

19 As might be expected, almost half speak from notes; at the same time more than a quarter read a prepared text. Some interesting information arises from the form of presentation specified by those who marked autres. Of these, 17 indicated that their papers take the form of a commentary on transparencies or slides. A further 6, even more surprisingly, say that they speak without notes (parler sans notes), though it is possible that these too are using some sort of support such as transparencies or slides. Some indeed indicated this with remarks such as sans notes + transparents, plan élaboré à partir d'une série de transparents et/ou diapositives, parler tout court à partir de diapos. One, presumably humorous, correspondent described his method as mauvaise improvisation.

There are a number of pedagogical points that can be made about these results. Most people would accept that reading a prepared text is hardly the best method of communicating a message. The fact that almost half speak from notes is significant in itself. On the other hand it is understandable that the prepared text gives the non-native speaker a sense of security in a situation which he may well find daunting. There would therefore seem to be a place for training scientists in speaking from notes in English. The type of presentation which takes the form of a commentary on transparencies or slides seems to be a sector whose importance has not yet been realised. Here again it would seem that training in this form of presentation would be appropriate. Saying that training in these two areas needs to be introduced or expanded naturally implies that there is also a need for (further) research on these subgenres.

\section{Preparing for a presentation}

21 Correspondents were asked how they set about preparing for giving a presentation at a conference. The replies were as follows.

Table 8. Pour préparer une communication en anglais, quelle stratégie utilisez-vous ?

\begin{tabular}{|l|l|}
\hline préparer vous-mêmes (sans aide) & 60 \\
\hline demander de l'aide à un(e) collègue scientifique anglophone & 20 \\
\hline demander de l'aide à un(e) collègue scientifique non-anglophone & 14 \\
\hline
\end{tabular}




\begin{tabular}{|l|l|}
\hline demander de l'aide à un(e) collègue/ami(e) anglophone non-scientifique & 8 \\
\hline demander de l'aide à un(e) collègue/ami(e) angliciste (non-anglophone) non-scientifique & 6 \\
\hline autres (préciser) & 3 \\
\hline
\end{tabular}

In view of the admitted difficulty of the task, it seems highly surprising that almost two out of three of the replies indicate that the correspondent seeks no linguistic help in preparing a paper for presentation. Where help is sought, some marked more than one category. Moreover it appears that in seeking help, scientists are thought preferable to non-scientists, with a ratio of 34:14. To a rather lesser extent, English-speakers seem to be preferred to non-English-speakers with a ratio of 28:20, though this may be conditioned by the availability of English-speakers; perhaps there are just not enough of them around. There also seems to be a preference for a non-English-speaking scientist as opposed to an English-speaking non-scientist, with a ratio of 14:8. These figures seem to indicate that scientists rate scientific competence higher than linguistic competence even for this purpose which is basically linguistic in nature.

It is also worth pointing out that at this particular university a service is available which provides help for researchers in producing documents in English. The service is staffed by one francophone scientist. Some of the correspondents indicated that they use this service, while others, particularly in the Medical Faculty did not seem to be aware of its existence.

\section{Scientists' perception of the problem}

It is a commonly held belief that French scientists experience more difficulty dealing with the social aspects of conferences than in the actual presentation of a paper. That is, what causes them most difficulty is casual conversation in English outside of the conference hall itself. The results of this questionnaire do not confirm this belief. Correspondents were asked to grade three tasks as being très difficile, assez difficile or pas difficile; the three tasks were présenter une communication en anglais, participer aux discussions/débats en anglais and participer aux manifestations sociales en anglais. The results were as follows.

Table 9.1. À quel point trouvez-vous les tâches suivantes difficiles ? Présenter une communication en anglais

\begin{tabular}{|l|l|}
\hline très difficile & 20 \\
\hline assez difficile & 45 \\
\hline pas difficile & 33 \\
\hline
\end{tabular}

Table 9.2. À quel point trouvez-vous les tâches suivantes difficiles ? Participer aux discussions/débats en anglais

très difficile 37 


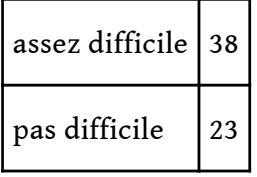

Table 9.3. À quel point trouvez-vous les tâches suivantes difficiles ? Participer aux manifestations sociales en anglais

\begin{tabular}{|l|l|}
\hline très difficile & 18 \\
\hline assez difficile & 42 \\
\hline pas difficile & 33 \\
\hline
\end{tabular}

These figures indicate that the scientists in question find participating in social events no more difficult than giving a presentation. The raw figures for très difficile and assez difficile in relation to social events are fractionally lower, but a few correspondents left this section blank. What the scientists do suggest is more difficult for them is taking part in debates and discussion. Compared with giving a paper, almost twice as many found taking part in debates and discussion très difficile, while almost a third less found it pas difficile. Some correspondents emphasised the difficulty they experience in this area. One put two crosses in the très difficile box, and another drew in an extra box and wrote in impossible. French scientists seem to have more difficulty with certain regional varieties of English. American English seems to cause more problems than British, and Texans are said to be particularly difficult. As one correspondent wrote on his questionnaire "cela dépend des interlocuteurs, les texans sont incompréhensibles". Many correspondents have the feeling that Americans in particular make no concessions to non-native speakers of English.

Once again there seem to be pedagogical implications in these findings. Taking part in spontaneous debate and fielding questions is evidently an area where French scientists feel insufficiently confident, and consequently at a disadvantage in the international situation. There is therefore a case for giving special attention to this question in the English training given to scientists.

\section{Training}

The scientists who replied to the questionnaire have a very poor opinion of the English training they have received. When asked about this the results were as follows.

Table 10. Est-ce que votre formation en anglais vous a préparé pour la tâche de communiquer en anglais?

\begin{tabular}{|l|l|}
\hline oui, très bien & 2 \\
\hline oui, assez bien & 10 \\
\hline adéquat & 10 \\
\hline
\end{tabular}


non, pas de tout 75

$$
\begin{aligned}
& \text { this type of task. This, of course, must be taken in the context of the age range concerned. } \\
& \text { However, while there have undoubtedly been some changes in recent years, the suspicion } \\
& \text { must remain that the situation has not changed essentially. }
\end{aligned}
$$

\section{Conclusion} noticeable recent developments in this area has been the use of PRAGs recruited in many universities specifically for the purpose of teaching English to students studying subjects other than English itself. This is notably so in many science faculties. While no-one would wish to cast doubt on the competence of the PRAGs concerned, it remains true that they have themselves had no specific training in this area, and very few of them seem to develop a special interest in ESP, since when they undertake research it is rarely in the ESP domain. While I feel that this policy may be justified in the short term in so far as there is a lack of suitably qualified people for the moment, one might hope that as the numbers with specific qualification in ESP grows, then this will be matched by the creation of suitable enseignant-chercheur posts in our science faculties, so that the teaching of ESP will be done by those who have been trained and have a research interest in that area.

In relation to the last two points made above, it is worth pointing out that a pool of persons qualified in ESP is now being built up in France through the DEA Langue Anglaise des Spécialités Scientifiques et Techniques, Méthodologie de la recherche linguistique, didactique, culturelle, technologique. This DEA is organised jointly by the universities of Bordeaux 2, Montpellier 3, Toulouse 1, Paris 4 and ENS Cachan. I would like to suggest that those who have obtained this qualification might be suitable candidates for services dedicated to 
helping scientists in their difficulties with English, and that those who go on to obtain a doctorate are specifically qualified for the task of teaching English in science faculties.

\section{APPENDIXES}

\section{Annexe}

\section{Questionnaire : le scientifique français et la langue anglaise}

Quel est votre domaine de recherche?

- biologie

- chimie

- informatique

- mathématiques

- médecine

- physique

- technologie

- autres (préciser)

Dans quelle tranche d'âge vous situez-vous?

- moins que 30 ans

- 30 - 39

- $40-49$

- $50-59$

- 60 et plus

Quel est votre sexe?

$\mathrm{M} / \mathrm{F}$

Quelle est votre langue maternelle?

- le français :

- autres (préciser) :

À combien de colloques/symposiums/congrès avez vous assisté depuis le $1^{\mathrm{er}}$ janvier 1997 ?

- en France :

- dans les pays anglophones :

- ailleurs :

À combien de colloques/symposiums/congrès avez vous communiqué depuis le $1^{\mathrm{er}}$ janvier 1997 ?

- en France :

- dans les pays anglophones :

- ailleurs :

Quelles langues étaient utilisées pour la présentation des communications? 
En France :

- le français

- l'anglais

- autres (préciser)

En pays anglophones :

- le français

- l'anglais

- autres (préciser)

Ailleurs :

- le français

- l'anglais

- autres (préciser)

Dans quelle langue présentez-vous vos communications?

En France :

- le français

- l'anglais

- autres (préciser)

En pays anglophones :

- le français

- l'anglais

- autres (préciser)

Ailleurs :

- le français

- l'anglais

- autres (préciser)

Si vous communiquez en anglais, comment le faites-vous?

- Lire un texte écrit

- Parler à partir de notes

- Autres (préciser)

Pour préparer une communication en anglais, quelle stratégie utilisez-vous?

préparer vous-mêmes (sans aide)

demander de l'aide à un(e) collègue scientifique anglophone

- demander de l'aide à un(e) collègue scientifique non-anglophone

- demander de l'aide à un(e) collègue/ami(e) anglophone non-scientifique

- demander de l'aide à un(e) collègue/ami(e) angliciste (non-anglophone) nonscientifique

- autres (préciser)

À quel point trouvez-vous les tâches suivantes difficiles?

Présenter une communication en anglais :

- très difficile 
- assez difficile

pas difficile Participer aux discussions/débats en anglais :

- très difficile

- assez difficile

pas difficile Participer aux manifestations sociales en anglais :

- très difficile

- assez difficile

- pas difficile

Est-ce que votre formation en anglais vous a préparé pour la tâche de communiquer en anglais?

- Oui, très bien

- Oui, assez bien,

- Adéquat

Non, pas du tout Si vous avez des remarques ou commentaires à ce sujet, veuillez les ajouter ici :

Seriez-vous prêt à être interviewé à ce sujet, pour la suite de l'étude ?

Si oui, veuillez ajouter vos coordonnées :

Nom :

Adresse :

Tél. :

e-mail :

Retourner à : David Banks, Faculté des Lettres et Sciences Sociales Victor Segalen, Université de Bretagne Occidentale.

\section{ABSTRACTS}

There seems to be a tendency in the ESP area to attribute opinions and attitudes to scientists, with insufficient justification. This paper presents the results of a questionnaire which attempts to rectify this situation in relation to the use of English at conferences. It shows that while many commonly held beliefs are confirmed, the importance of some types of presentation has been underestimated, and taking part in debates and discussion is found to be particularly difficult. These facts need to be taken into account in the training given to scientists and in the linguistic services which are set up to help them.

Dans le domaine de l'anglais de spécialité, il semble y avoir une tendance à attribuer, sans véritable fondement, des opinions et des attitudes aux scientifiques. La présente contribution présente les résultats d'un questionnaire qui tente de rectifier cette situation en ce qui concerne l'usage de l'anglais dans les congrès. Elle démontre, malgré la confirmation de beaucoup d'idées reçues, que l'importance de certains types de présentation est sous-estimée, et que la participation aux débats et aux discussions pose des problèmes particuliers. Il faut prendre en compte ces données dans la formation des scientifiques et dans les structures de services linguistiques mises en place pour les aider. 
INDEX

Keywords: presentation, questionnaire, scientific conference, scientific English, training

Mots-clés: anglais scientifique, communication, congrès scientifique, formation, questionnaire

\section{AUTHOR}

DAVID BANKS

David Banks est professeur à l'Université de Bretagne Occidentale à Brest. Il est l'auteur, notamment, de Writ in Water, Aspects of the Scientific Journal Article (1993, ERLA, Brest) et rédacteur de ESP France Newsletter. David.Banks@univ-brest.fr 